Creative Commons User License: CC BY-NC-ND

Abstracted by: EBSCOhost, Electronic Journals Service (EJS),

Google Scholar, Journal Seek, Scientific Commons,

Food and Agricultural Organization (FAO), CABI and Scopus

http://eoi.citefactor.org/10.11226/v24i3
Journal of Agricultural Extension

Vol. 24 (3) July, 2020

ISSN(e): 24086851; ISSN(Print); 1119944X

http://journal.aesonnigeria.org

http://www.ajol.info/index.php/iae

Email: editorinchief@aesonnigeria.org

\title{
Factors Determining Continuous Tractor Use in Benin Republic
}

\section{https://dx.doi.org/10.4314/jae.v24i3.10}

\author{
Dayou, Ephrème Dossavi \\ School of Environmental Management, \\ Faculty of Agronomic Sciences, \\ University of Abomey-Calavi, Abomey-Calavi, Benin Republic. \\ Department of Environmental Management, \\ Pan African University Life and Earth Sciences Institute, \\ University of Ibadan, Ibadan, Nigeria. \\ Email:phreddoss1@yahoo.fr \\ Phone: +22967904166
}

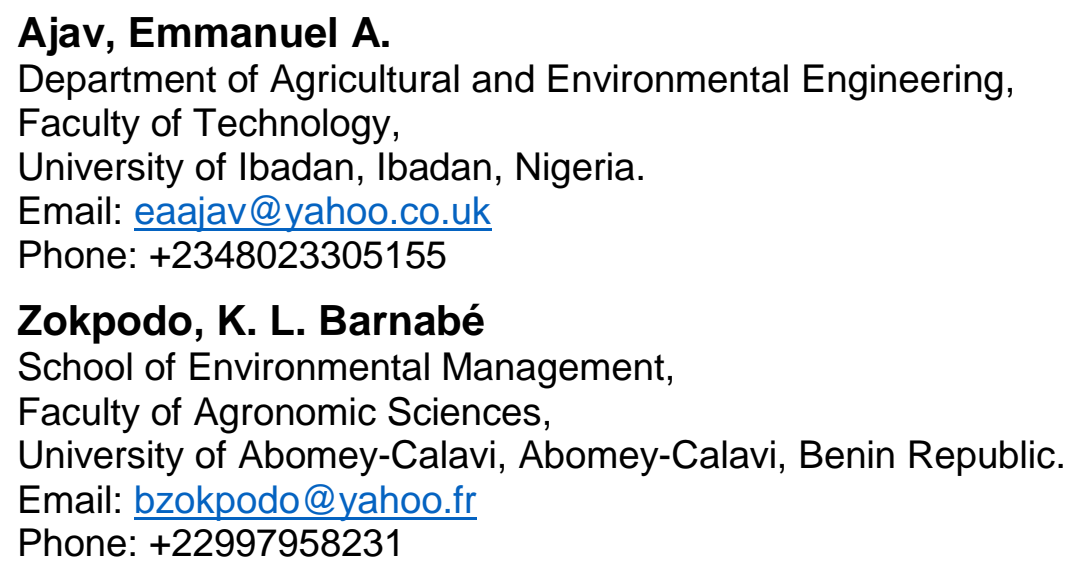

\section{Bamgboye, A. Isaac}

Department of Agricultural and Environmental Engineering,

Faculty of Technology,

University of Ibadan, Ibadan, Nigeria.

Email: isaacbam22@yahoo.com

Phone: +2348037190626

\section{Glèlè Kakaï, L. Romain}

Laboratory of Biomathematics and Forestry Estimations,

Faculty of Agronomic Sciences,

University of Abomey-Calavi, Abomey-Calavi, Benin Republic.

Email: glele.romain@gmail.com

Phone: +22995840800

\section{Abstract}

This study investigated the factors determining continuous tractor use in Benin. A multi stage sampling procedure was used to select tractor users in the country. A total of 203 households using agricultural machinery were surveyed through interviews and using a structured questionnaire. The information concerned socioeconomic characteristics, the equipment used and agricultural production. The logit model was used for data analysis. About $75 \%$ of tractor owners 
Creative Commons User License: CC BY-NC-ND

Abstracted by: EBSCOhost, Electronic Journals Service (EJS),

Google Scholar, Journal Seek, Scientific Commons,

Food and Agricultural Organization (FAO), CABI and Scopus
Journal of Agricultural Extension

Vol. 24 (3) July, 2020

ISSN(e): 24086851; ISSN(Print); 1119944X

http://journal.aesonnigeria.org

http://www.ajol.info/index.php/iae

Email: editorinchief@aesonnigeria.org

use it for service delivery, while $71.4 \%$ of them possess their own land. Continuous use of tractor is significantly influenced by the number of hours for one hectare tilled, the total area tilled per year as well as the tractor age. Moreover, the tractor brands available in the country also influenced tractor use. The hierarchized failures were hydraulic lifting pump (16.4\%), fuel filter (14.6\%), clutch disc failure (9.9\%), breakage of plough (8.8\%) and injection pump (7.6\%). The future of agricultural equipment use can now be anticipated and take action to deal with any tractor use difficulties for sustainable agricultural extension in Benin.

Keywords: Farm machinery, adoption, failure, Benin Republic.

\section{Introduction}

In Africa, agriculture provides employment for the majority of the population and contributes a significant proportion of the gross domestic product. Despite its crucial role, agriculture is largely underdeveloped in most African countries (Zhou, 2016). Low levels of input use and mechanization have been cited as the main constraints to agricultural development. Due to the fact that greater mechanization leads to increased higher food production, enhanced food security and reduced dependence on imports, several farmers are engaged in the use of agricultural machinery by purchasing their own tractor or through. In many African countries, mechanization efforts before the 1980s focused on governments importing large tractors and leasing them out under public programmes.

However, despite enormous efforts such as donations, subsidies for machinery, dutyfree imports, some challenges like lack of spare parts and adequate experts lead to long downtimes (Ströh de Martínez, Feddersen and Speicher, 2016). In Benin, the acquisition of machinery is difficult due to the lower income of farmers. It is moreover complicated to find adequate and affordable machinery. As a result, most cooperatives depend on intermediaries such as government funds or NGOs to acquire or import the necessary machinery (Fondation pour l'Agriculture et la Ruralité dans le Monde (FARM), 2015). It is known that tractors are an indispensable source of energy in agriculture. However, it is essential to recognize that the mechanization process is characterized by interrelated and fundamental changes in the agricultural system (Food and Agriculture Organization (FAO, 2018) of the United Nations and the African Union Commission (AUC, 2018). Tractor uses are face with problems of frequent failures, and significant operating costs resulting from the continued use of agricultural tractors are related to repair and maintenance costs (Silveira, Machado, Amaral, Santos and Rodrigues, 2020). To reduce these costs and make the production profitable, machinery breakdown classification is essential for farmers to plan for spare parts requirements and to be prepared to deal with tractor breakdown in the field (Al-Suhaibani and Wahby, 2015). Despite these difficulties many farmers continue to use these tractors and machinery.

The study examined factors determining the continuous tractor and pre-harvest equipment use in Benin Republic. Specifically, it examined what motivates tractor users, the tractor brands used and the major crops for which the machinery is used. The misuse and failures of machinery met by farmers were also concerned. 
Creative Commons User License: CC BY-NC-ND

Abstracted by: EBSCOhost, Electronic Journals Service (EJS),

Google Scholar, Journal Seek, Scientific Commons,

Food and Agricultural Organization (FAO), CABI and Scopus
Journal of Agricultural Extension

Vol. 24 (3) July, 2020

ISSN(e): 24086851; ISSN(Print); 1119944X

http://journal.aesonnigeria.org

http://www.aiol.info/index.php/iae

Email: editorinchief@aesonnigeria.org

\section{Methodology}

The study was carried out in Benin Republic (West Africa). The country is located in the tropical zone between the Equator and the Tropic of Cancer, between $6^{\circ} 30^{\prime}$ and $12^{\circ} 30^{\prime}$ north and $1^{\circ}$ and $3^{\circ} 40^{\prime}$ east Meridian. With a total area of $114,763 \mathrm{~km}^{2}$, it accounts 77 Municipalities and 7 Poles of Agricultural Development administered by Territorial Agencies of Agricultural Development (ATDA). The mean annual rainfall distribution of this country is ranged from $900 \mathrm{~mm}$ to $1300 \mathrm{~mm}$ with an annual temperature of $26-28^{\circ} \mathrm{C}$.

A multi stage sampling procedure was used to select tractor users in the country from the data from the latest Benin General Population and Housing Census (RGPH4) of the National Institute of Applied Statistics and Economy (INSAE, 2016) and data from the report of the Programme of Agricultural Mechanization Development of the Ministry of Agriculture, Livestock and Fishery of Benin (MAEP, 2016). These data provided information on the total number of agricultural workers, the level of mechanization and the proportion of households using mechanical equipment in agriculture by department and municipality. The number of tractors and equipment distributed in Benin by the Programme of Promotion of Agricultural Mechanization (PPMA) is estimated at 1040 tractors.

Then, 43 municipalities were selected among 77 municipalities of the country. The selection criteria were the level of agricultural machinery use and the location of these municipalities in different departments and poles of agricultural development. The pole of agricultural development represents a development territory organized on a limited number of priority sectors, driving the economic development of a group of municipalities. The number of people surveyed per municipality was determined by considering the percentage of tractor users in each municipality in the total proportion of the department and pole of agricultural development. Finally, a total of 203 households using mechanical equipment in agriculture were surveyed through interviews using a structured questionnaire. The information concerned socioeconomic characteristics, tractors and equipment use, and production activities.

The logit model was used to assess the determinants of continuous use of tractors by farmers. Mango, Makate, Tamene, Mponela and Ndengu, (2017) showed that technology adoption is affected by factors such as sociodemographic characteristics, absence of equipment to relieve labour shortages, inadequate farm size, farm tenure arrangements, insufficient complementary inputs and inappropriate transport infrastructure, availability of credit. The odds of continuous use of tractor by farmers was represented as $Y=1$ while the odds of no continuous use of tractor was $Y=0$.

The regression model showing the probability $\left(\mathrm{P}_{\mathrm{i}}\right)$ of continuous use of tractor $(\mathrm{Y})$ was given as:

$$
P_{i}(Y)=1 /\left(1+\exp \left(-z_{i}\right)\right)
$$

Where $Z_{i}$ is a function given by:

$$
Z_{i}=b_{0}+b_{1} X_{1}+b_{2} X_{2}+\ldots \ldots+b_{n} X_{n}
$$


Where $b_{i}$ are regression coefficients which indicate the probability effect of farmers' attributes and $X_{i}$ are farmers' socio-demographic characteristics, the characteristics of tractor and equipment, the mechanized area and technical failures associated with tractors variables.

The model assumed that the continuous use of tractor by farmers depends significantly on the socio-demographic, the mechanized area, tractor brand, tractor use input, equipment and relative failure. A stepwise selection of explanatory variables was conducted. The odds-ratio was then calculated (Chongsuvivatwong, 2018) in order to identify the factors determining the continuous use of tractors by producers in Benin. The Fisher test was conducted to assess the dependence between the tractor brands used by producers and the failures they had. Finally, a factorial correspondence analysis was carried out to describe the relationship between tractors and failures. All the analyses were performed under $\mathrm{R}(\mathrm{R}$ Core Team, 2019) and the level of significance of the statistical tests was $5 \%$.

The following variables were measured as binary: sex, farming as main activity, type of operation mechanized, tractor brand, type of acquisition, state of tractor at the time of purchase, tractor currently used, source of tractor funded, presence of tractor parking, type of parking, presence of repair centre, ownership of the repair centre. Variables measured as discrete were school level, part of cooperative, land access, tractor use appreciation, number of tractors, horse power of the tractors, number of equipment in use. Continuous variables measured were age of tractor users, number of hour to plough one ha, number of ha ploughed per year, quantity of fuel used for one ha tilled, number of ha mechanized, tillage cost, tractor purchase price, tractor age.

\section{Results and Discussion}

\section{Socio-Economic Characteristics of Tractor Users}

Table 1 shows that the class of age 40-60 years is most represented and the sampled informants are mostly male $(96.1 \%)$. Moreover, most respondents attended school class. Some of them have farming as main activity (72.9\%) with an average tractor use experience of 4.3 years. 
Creative Commons User License: CC BY-NC-ND

Abstracted by: EBSCOhost, Electronic Journals Service (EJS),

Google Scholar, Journal Seek, Scientific Commons,

Food and Agricultural Organization (FAO), CABI and Scopus

http://eoi.citefactor.org/10.11226/v24i3
Journal of Agricultural Extension

Vol. 24 (3) July, 2020

ISSN(e): 24086851; ISSN(Print); 1119944X

http://journal.aesonnigeria.org

http://www.aiol.info/index.php/iae

Email: editorinchief@aesonnigeria.org

Table 1: Tractors users' socio-economic characteristics

\begin{tabular}{lcc}
\hline Variables & $\begin{array}{c}\text { Percentage of } \\
\text { users }(\mathbf{n = 2 0 3})\end{array}$ & $\begin{array}{c}\text { Mean (Standard } \\
\text { deviation) }\end{array}$ \\
\hline Age (years) & 8.4 & \\
$<40$ & 84.7 & $49.3(7.1)$ \\
$40-60$ & 6.9 & \\
$>60$ & & \\
Sex & 96.1 & \\
Male & 3.9 & \\
Female & & \\
Education & 30.1 & \\
No formal education & 28.1 & \\
Primary education & 26.6 & \\
Secondary education & 15.3 & \\
Tertiary education & & \\
Importance of farming & 72.9 & \\
Main Activity & 27.1 & \\
Secondary activity & & \\
Tractor use experience (years) & 90.2 & \\
1-8 & 9.9 & \\
9-15 & 0 & \\
$>15$ & &
\end{tabular}

Source: Data from survey, 2019

Table 2 shows that $75.4 \%$ have tractor use as their own business and only $14.8 \%$ are part of farmers' cooperatives. Furthermore, $71.4 \%$ are land owners and all of them recognize the positive effects of tractor use on farm productivity. The majority of farmers $(99.5 \%)$ continue to use mineral fertilizers. The higher percentage of tractor users as own business is a great contribution to allow the other farmers without tractors to benefit for this service. This form of tractor service delivery is encouraged by Houssou, Asante-Addo, Diao and Kolavalli (2015) who declared that it was only through hiring that tractor service charges could be reduced sufficiently to enable most farmers to adopt mechanized technologies, encouraging many to invest in private tractor service provision.

Concerning machinery status, $85.2 \%$ of tractor are purchased as new and 84.7 of tractors are half-funded by the government. About $72.9 \%$ of tractors are currently used among $76.4 \%$ still functional. But the lack of parking (53.2\%) and absence of repair centre $(97.5 \%)$ are a concern. The exposure of the tractor to the weather causes some breakdowns and additional repair costs. It will be difficult to smallholder farmers because they are generally poor and their incomes are also low (Rapsomanikis, 2015). The lack of repair centre will aggravate the situation, leading farmers to withdraw from using tractors. In fact, repair and maintenance constitute a main component of the operating costs of agricultural machinery. Added to the accumulated hours of operation, they are essential in the optimum life of tractors (AlSuhaibani and Wahby, 2015). The creation of repair centres and farmers' training on 
Creative Commons User License: CC BY-NC-ND

Abstracted by: EBSCOhost, Electronic Journals Service (EJS),

Google Scholar, Journal Seek, Scientific Commons,

Food and Agricultural Organization (FAO), CABI and Scopus

http://eoi.citefactor.org/10.11226/v24i3
Journal of Agricultural Extension

Vol. 24 (3) July, 2020

ISSN(e): 24086851; ISSN(Print); 1119944X

http://journal.aesonnigeria.org

http://www.aiol.info/index.php/iae

Email: editorinchief@aesonnigeria.org

tractor caring will reduce these problems. That could increase the demand for mechanization inputs and lead to higher productivity (Sims and Kienzle, 2016).

Table 2: Ownership and status of tractor use

\begin{tabular}{llc}
\hline Parameters & Variables & $\begin{array}{c}\text { Percentage of } \\
\text { users (n=203) }\end{array}$ \\
\hline \multirow{3}{*}{ Part of cooperative } & Users' practices and perceptions & \\
& CUMA & 14.8 \\
& Personal use and service delivery & 75.4 \\
Land access & Government agency & 9.9 \\
& Legacy & 71.4 \\
& Purchase & 9.9 \\
& Legacy+purchase & 13.5 \\
Effect of tractor use on farm & Gift & 5.2 \\
productivity & Nont effect & 0 \\
& Small effect & 0 \\
Mineral fertilizer users & Important & 0.5 \\
Organic fertilizer users & Very important & 49.8 \\
Mixed (mineral+organic) & - & 49.8 \\
State in the purchase & - & 99.5 \\
& Tractors' characteristics & 0.5 \\
Funded & New & 8.9 \\
Still functional & Second user & \\
Currently used & - & 85.2 \\
Type of parking & - & 14.8 \\
& - & 84.7 \\
Presence of repair centre & No parking & 76.4 \\
Owner of repair centre & Traditional & 72.9 \\
\hline Source: Dat & - & 53.2 \\
& Modern & 30.1 \\
& - & 16.8 \\
& & 2.5 \\
& & 2.0 \\
\hline
\end{tabular}

Source: Data from survey, 2019

\section{Determinants of Continuous Tractor Use}

Table 3 shows that the continuous use of tractor is significantly influenced by the number of hour for one ha tilled, the total area tilled per year as well as the tractor age (Table 3; $\mathrm{P} \leq 0.05$ ).

Table 3: Factors determining continuous tractor use in Benin 
Creative Commons User License: CC BY-NC-ND

Abstracted by: EBSCOhost, Electronic Journals Service (EJS),

Google Scholar, Journal Seek, Scientific Commons,

Food and Agricultural Organization (FAO), CABI and Scopus

http://eoi.citefactor.org/10.11226/v24i3
Journal of Agricultural Extension

Vol. 24 (3) July, 2020

ISSN(e): 24086851; ISSN(Print); 1119944X

http://journal.aesonnigeria.org

http://www.aiol.info/index.php/iae

Email: editorinchief@aesonnigeria.org

\begin{tabular}{|c|c|c|c|c|c|c|}
\hline \multirow[b]{2}{*}{ Variables } & \multicolumn{3}{|c|}{ Logit model } & \multicolumn{3}{|c|}{ Odd ratio (OR) } \\
\hline & Coefficients & $\begin{array}{l}\text { Wald } \\
\mathrm{Khi}^{2}\end{array}$ & $\begin{array}{l}\mathrm{Pr}> \\
\mathrm{Khi}^{2}\end{array}$ & Value & ORmin & ORmax \\
\hline Intercept & 0.68 & 0.203 & 0.653 & - & - & - \\
\hline Number of hour for 1 ha tilled & -0.68 & 5.745 & 0.017 & 0.52 & 0.31 & 0.89 \\
\hline Mechanized area & 0.01 & 7.671 & 0.006 & 1.01 & 1.00 & 1.02 \\
\hline Tillage cost & 0.00 & 3.471 & 0.062 & 1.00 & 1.00 & 1.00 \\
\hline Tractor age & -0.29 & 13.758 & 0.000 & 0.75 & 0.65 & 0.87 \\
\hline Number of rotary cutter & 31.36 & 0.000 & 1.000 & & - & \\
\hline
\end{tabular}

Table 3, shows that when the time to till one hectare (ha) increased by one hour the odds of tractor use decreased by $48 \%$ (OR-1; OR=0.52). The odds of using a tractor increased by $1 \%$ when the area tilled increased by one ha $(O R-1$; OR $=1.01)$. The motivation of tractor users based on tillage time's reduction and the tilled area increasing can be explained by the fact that farmers understand that adoption of technologies leads to improved yields of crops which translate into increased income and improved quality of life of farmers (Ejechi, 2015).

The tillage cost does not influence directly the tractor use odds $(\mathrm{OR}=1)$ because apart some particular ways, it is fixed around 30,000 FCFA over the country. However, the increasing of tractor age reduces the odds of tractor use by $25 \%$ (OR1 ; OR=0.75).

\section{Tractor Brands Effects on Tractor Use}

Tractor brands available also influenced tractor use (Table 4; $\mathrm{P} \leq 0.05$ ). Thus, the availability of a Mahindra tractor increased the odds of using a tractor by a factor of 5.31 , while the availability of a Farmtrac tractor decreased the odds of ploughing with a tractor by $74 \%(\mathrm{OR}-1$; OR $=0.26)$.

Table 4: Effect of Tractor brands on tractor use in Benin

\begin{tabular}{|c|c|c|c|c|c|c|}
\hline \multirow[t]{2}{*}{ Variable } & \multirow[b]{2}{*}{ Coefficients } & \multicolumn{2}{|c|}{ Logit model } & \multicolumn{3}{|c|}{ Odd ratio (OR) } \\
\hline & & $\begin{array}{l}\text { Standard } \\
\text { error }\end{array}$ & $z$-value & Value & ORmin & ORmax \\
\hline (Inter & 0.26 & 0.35 & 0.74 & . & . & 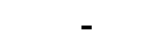 \\
\hline $\begin{array}{l}\text { Tractor brand } \\
\text { (Mahindra) }\end{array}$ & 1.67 & 0.54 & $3.10^{*}$ & 5.31 & 1.85 & 15.25 \\
\hline $\begin{array}{l}\text { Tractor brand } \\
\text { (Farmtrac) }\end{array}$ & -1.35 & 0.45 & $-3.02^{*}$ & 0.26 & 0.11 & 0.62 \\
\hline
\end{tabular}

${ }^{*} \leq 0.05$. Test of adequacy: $\left.X^{2}=161.31 ; d f=182 ; P=0.862\right) ;$ ORmin and ORmax $=$ lower and upper limits of the $95 \%$ confidence interval of the odd ratio;

These results indicate that tractor user who found the technology profitable retained it. More time to till is negatively correlated with tractor users' decision because farmers know that the advantage of using tractors is time savings, and tractor services could significantly increase the returns in agricultural production (Takeshima, 2017). The tilled area increasing motivates to tractor use. It is due to the fact that land holding has significantly and positively influencing the tractor hiring 
Creative Commons User License: CC BY-NC-ND

Abstracted by: EBSCOhost, Electronic Journals Service (EJS),

Google Scholar, Journal Seek, Scientific Commons,

Food and Agricultural Organization (FAO), CABI and Scopus

http://eoi.citefactor.org/10.11226/v24i3
Journal of Agricultural Extension

Vol. 24 (3) July, 2020

ISSN(e): 24086851; ISSN(Print); 1119944X

http://journal.aesonnigeria.org

http://www.aiol.info/index.php/iae

Email: editorinchief@aesonnigeria.org

service and land size has impact on use of tractor (Takele and Selassiez, 2018). Furthermore, years of experience could affect adoption of farm mechanization positively or negatively.

\section{Mechanized crops}

Table 5 illustrates the mechanized crops in the country using these tractors and equipment.

Table 5: Mechanized crops by farmers

\begin{tabular}{lc}
\hline Crops & Percentage of users $(\mathrm{n}=203)$ \\
\hline Maize & 85.7 \\
Cotton & 68.5 \\
Rice & 16.8 \\
Sorghum & 26.1 \\
Soybean & 26.1 \\
Groundnut & 7.9 \\
Cowpea & 4.9 \\
Cassava & 11.8 \\
Coconut & 1.0 \\
\hline
\end{tabular}

Source: Data from survey, 2019

Maize and cotton are the most mechanized crops by farmers $(85.7 \%$ and $68.5 \%$ respectively). It is due to the importance of these crop, maize as one of major foods and cotton for his economic profit. Mechanized the farm is sometime an honour for farmer, because a farmer who ploughs his land with a tractor is called an innovator (Takele and Selassiez, 2018). However, the contribution of tractor for farm size increasing and the final production is not neglected by farmers. Small and mediumsized farmers benefit from a gain economy when they adopt agricultural mechanization, as they are able to increase their level of production (Ayandiji and Olofinsao, 2015).

With regard to the importance of punctuality in farming operations, many studies have shown the yield loss incurred by late seeding (and weeding). This can be as much as $1 \%$ per day late for many crops (Sims and Kienzle, 2016; Baudron et al., 2015). Then, farmers continue to use the tractors based on its contribution for the production. Like found by Gokul, Dilli, Dil, Scott and Andrew (2019), in Nepal, the adoption of the mini-tiller has a significant and positive impact on rice productivity and, furthermore, if the mini-tiller adopters had not adopted mini-tillers, their rice productivity would have decreased, and if the non-adopters had adopted the minitillers, their rice productivity would have increased.

\section{Relationship between Different Tractor Brands and Major types of Breakdowns}

The most common tractor brands used by producers were Mahindra $(42.4 \%$ of tractors), Farmtrac (20.7\%) Massey Ferguson (20.7\%) and Sonalika (19.2\%). The most common failures were hydraulic lifting pump (16.4\%), fuel filter (14.6\%), clutch disc failure $(9.9 \%)$, broken of plow (8.8\%) and injection pump (7.6 \%). Fisher's exact test indicated a significant dependence between the tractor brands and the type of 
Creative Commons User License: CC BY-NC-ND

Abstracted by: EBSCOhost, Electronic Journals Service (EJS),

Google Scholar, Journal Seek, Scientific Commons,

Food and Agricultural Organization (FAO), CABI and Scopus
Journal of Agricultural Extension

Vol. 24 (3) July, 2020

ISSN(e): 24086851; ISSN(Print); 1119944X

http://journal.aesonnigeria.org

http://www.ajol.info/index.php/iae

Email: editorinchief@aesonnigeria.org

failures $(P<0.001)$. The results of the factor analysis of the correspondences carried out on the brands of tractors and the types of failures indicated that the first two factorial axes retained $59.3 \%$ of the total inertia. It follows from the joint projection of the tractor brands and types of failures in the main plan that the failures of the fuel tank, fuel filter, starter, air taken, and broken of locking pin were more associated with Mahindra tractor brands. Likewise, the John Deree, SF554R and SWT904 brands often had steering wheel and gear box failures. The OUQI brand was also characterized by gear box breakdowns. Rear box crashes were more often associated with the Farmtrac brand and tire crashes were more common with Sonalika. Alternator failures were mostly associated with Sonalika and Mahindra.

This classification of repair and maintenance in tractors is very important for identifying the major causes of breakdowns. It helps farmers to plan for spare parts requirements and to be prepared to deal with any tractor breakdown in the field (AlSuhaibani and Wahby, 2015).

\section{Conclusion and Recommendations}

The rapidity of tillage operation, the total area tilled per year as well as age of the tractor (recently purchase) were the most important factors motivating tractor use. This determination is also influenced by the type of crop, farmers preferred to mechanize the cereals and the commercial crops. Apart some cooperative use, many farmers are tractor owners and use them for service delivery. Tractor breakdowns are the most frequent difficulties that affect the use of the machines.

It is important to assist farmers by training them for a better use of machinery and reduce a misuse, because all functioning tractors are not currently used. Assistance could be done through a creation of some repair centres and spare parts shop closer to farmers. A mobile repair van with spare parts can also facilitate this issue. Added to the current half-funding policy, government may organize some meeting to follow the status of introduced tractors. To avoid certain breakdowns due to the exposure of tractors to the weather, it can be a requirement that each farmer must build a tractor parking lot or shed before acquiring the equipment.

\section{Acknowledgement}

This research was supported by the African Union through PAULESI.

\section{References}

Al-Suhaibani, S. A., Wahby, M. F. (2015). Farm tractors breakdown classification. Journal of the Saudi Society of Agricultural Sciences (2015), http://dx.doi.org/10.1016/i.jssas.2015.09.005

Ayandiji, A., Olofinsao, O. T. (2015). Socio economic factors affecting adoption of farm mechanization by cassava farmers in OndoState, Nigeria. IOSR Journal of Environmental Science, Toxicology and Food Technology, Volume 9, Issue 3 Ver. I, PP 39-45.

Baudron, F., Sims, B., Justice, S., Kahan, D., Rose, R., Mkomwa, S., Kaumbutho, P., Sariah, J., Nazare, R., Moges, G., et al. (2015). Re-examining appropriate mechanization in eastern and southern Africa: Two-wheel tractors, conservation agriculture, and private sector involvement. Food Secur. 2015, 7, 889-904. 
Creative Commons User License: CC BY-NC-ND

Abstracted by: EBSCOhost, Electronic Journals Service (EJS),

Google Scholar, Journal Seek, Scientific Commons,

Food and Agricultural Organization (FAO), CABI and Scopus
Journal of Agricultural Extension

Vol. 24 (3) July, 2020

ISSN(e): 24086851; ISSN(Print); 1119944X

http://journal.aesonnigeria.org

http://www.aiol.info/index.php/iae

Email: editorinchief@aesonnigeria.org

Chongsuvivatwong, V. (2018). epiDisplay: Epidemiological Data Display Package. R package version 3.5.0.1. https://CRAN.R-project.org/package=epiDisplay

Ejechi, M. E. (2015). Determinants of adoption of cassava technologies by male farmers in Nasarawa State, Nigeria. Journal of Agricultural Extension, Vol.19 (1) June, 2015, 11p. http://dx.doi.org/10.4314.jae.v19i1.10

Food and Agriculture Organization of the United Nations and the African Union Commission (FAO, AUC), (2018). Sustainable Agricultural Mechanization: A Framework for Africa. Addis Ababa, 127p.

Fondation pour l'Agriculture et la Ruralité dans le Monde (FARM). (2015). An original experience of shared mechanization in Africa: The Farm Machinery Cooperative in Benin, April 2015. Pp12-16.

Gokul, P. P., Dilli, B. K. C., Dil, B. R., Scott, E. J., Andrew, J. M. (2019). Scale-appropriate mechanization impacts on productivity among smallholders: Evidence from rice systems in the mid-hills of Nepal. Land Use Policy, Volume 85, June 2019, Pages 104-113. https://doi.org/10.1016/j.landusepol.2019.03.030

Houssou, N., Asante-Addo, C., Diao, X., Kolavalli, S. (2015). Big tractors, but small farms: Tractor hiring services as a farmer-owner's response to an under-developed agricultural machinery market. Working paper 39, 13p.

Institut National de la Statistique et de l'Analyse Economique (INSAE). (2016). Cahier des villages et quartiers de ville (RGPH-4, 2013), Août, 2016.

Ministère de l'Agriculture, de l'Elevage et de la Pêche (MAEP). (2016). Programme de developpement de la mecanisation de l'agriculture au Bénin. Rapport, Septembre 2016, $26 \mathrm{p}$.

Mango, N., Makate, C., Tamene, L., Mponela, P., Ndengu, G. (2017). Awareness and adoption of land, soil and water conservation practices in the Chinyanja Triangle, Southern Africa. International Soil and Water Conservation Research, 5, 122-129. https://doi.org/10.1016/j.iswcr.2017.04.003

Rapsomanikis, G. (2015). The economic lives of smallholder farmers: An analysis based on household data from nine countries. Food and Agriculture Organization of the United Nations, Rome, 2015. 39p.

R Core Team. (2019). R: A language and environment for statistical computing. $R$ Foundation for Statistical Computing. Vienna. Austria. URL https://www.R-project.org/.

Silveira, F., Machado, F. M., Amaral, F. G., Santos, B. M., Rodrigues, P. C. C. (2020). The proposition of factors for analysis of the maintenance of agricultural tractors from a systematic bibliographic review. GEPROS. Gestão da Produção, Operações e Sistemas, v. 15, n.1, p151-170, 2020. DOI: 10.15675/gepros.v15i1.2405

Sims, B., Kienzle, J. (2016). Making Mechanization Accessible to Smallholder Farmers in Sub-Saharan Africa. Environments 2016, 3, 11. Doi:10.3390/environments3020011

Ströh de Martinez, C., Feddersen M., Speicher, A. (2016). Food security in Sub-Saharan Africa: A fresh look at agricultural mechanization: how adapted financial solutions can make a difference. Studies 91, Deutsches Institut für Entwicklungspolitik, Bonn, 191p.

Takele, A. and Yihenew, G. S. (2018). Socio-economic analysis of conditions for adoption of tractor hiring services among smallholder farmers, Northwestern Ethiopia. Cogent Food \& Agriculture, 4:1, 1453978. https://doi.org/10.1080/23311932.2018.1453978

Takeshima, H. (2017). Custom-hired tractor services and returns to scale in smallholder agriculture: a production function approach. Agric. Econ. 48 (3), 363-372.

Zhou, Y. (2016). Agricultural mechanization in West Africa. Syngenta Foundation for Sustainable Agriculture, $11 p$. 